\title{
Heat-treatment and germination of oil palm seeds (Elaeis guineensis Jacq.) ${ }^{1}$
}

\author{
Márcia Green ${ }^{2 *}$, Wanderlei Antonio Alves Lima ${ }^{3}$, \\ Antenor Francisco de Figueiredo ${ }^{2}$, André Luiz Atroch ${ }^{3}$, Ricardo Lopes ${ }^{3}$, \\ Raimundo Nonato Vieira da Cunha ${ }^{3}$, Paulo Cesar Teixeira ${ }^{4}$
}

\begin{abstract}
Under natural conditions the germination of oil palm seeds may take years, and it is usually uneven and has a very low rate. To increase the germination rate it is necessary to break the dormancy, through heat-treatment (HT). In the germination of oil palm seeds produced by Embrapa Western Amazon the HT used is at $40{ }^{\circ} \mathrm{C}$ during 80 days. The objective of this study was to evaluate the periods of $40,50,60$ and 80 days of $\mathrm{HT}$ at $40{ }^{\circ} \mathrm{C}$ on seeds germination of six oil palm cultivars BRS C2001, BRS C2328, BRS C2501, BRS C2528, BRS C3701 and BRS C7201. The statistical design was randomized block, 6 x 4 factorial, with four replications of 500 seeds each. The minimum HT period for maximum germination ranged from 45 days for BRS C2328 (70\%) to 80 days for BRS C2528 (84\%). For BRS C7201 was not observed significant effect of the HT period for seed germination, estimated as $82 \%$. The maximum germination of oil palm seeds varies with the duration of heat treatment. With the exception of cultivar BRS C2528, heat treatment may be less than 80 days.
\end{abstract}

Index terms: oil palm, breaking dormancy, seed production.

\section{Tratamento térmico e germinação de sementes de dendezeiro (Elaeis guineensis Jacq.)}

\begin{abstract}
RESUMO - Em condições naturais, a germinação das sementes de dendezeiro pode demorar anos e, em geral, é baixa e desuniforme. Para aumentar a taxa de germinação destas sementes é necessário a superação da dormência, que é geralmente realizada por meio de tratamento térmico (TT). Para a germinação de sementes das cultivares de dendezeiro produzidas pela Embrapa Amazônia Ocidental, utiliza-se a temperatura de $40{ }^{\circ} \mathrm{C}$ por 80 dias. O objetivo desse estudo foi avaliar o efeito do TT a $40^{\circ} \mathrm{C}$, por períodos de 40, 50, 60 e 80 dias na germinação de sementes de seis cultivares de dendezeiro: BRS C2001, BRS C2328, BRS C2501, BRS C2528, BRS C3701 e BRS C7201. Foi utilizado o delineamento de blocos casualizados, em esquema fatorial $6 \times 4$, com quatro repetições de 500 sementes cada. O período mínimo de TT para germinação máxima variou de 45 dias para cultivar BRS C2328 (70\%) e 80 dias para a cultivar BRS C2528 (84\%). Para BRS C7201 não foi verificado efeito significativo do período de TT na germinação das sementes, estimada em $82 \%$. A germinação máxima das sementes de dendezeiro varia com duração do período de tratamento térmico. Com exceção da cultivar BRS C2528, o tratamento térmico pode ser inferior a 80 dias.
\end{abstract}

Termos para indexação: palma de óleo, dendê, superação de dormência, produção de sementes.

\section{Introduction}

The oil palm (Elaeis guineensis Jacq.) is native to Africa and, among oilseeds, it is the highest yielding oil crop, ranking first in the world in oil production, rising from 49,190,000 tons in the years $2007 / 2008$ to $56,270,000$ tons in 2011/2012, followed by soybeans, which in the years 2011/2012 produced 42,910,000 tons of vegetable oil (USDA, 2012).

The Brazilian Agricultural Research Corporation (Embrapa) is

${ }^{1}$ Submitted on 09/26/2012. Accepted for publication on 03/ 05/2013.

${ }^{2}$ Departamento de Produção Animal e Vegetal da Faculdade de Ciências Agrárias,

Universidade Federal do Amazonas, 69070-000 - Manaus, AM, Brasil. currently the only company in Brazil that runs a breeding program and handles commercial oil palm seed production. However, according to figures estimated by Embrapa Products and Markets' Unit in the State of Amazon, the amount of seed produced does not meet $50 \%$ of demand. While much of this deficit is related to the amount of seed produced in field crops, part of it is due to the losses occurring during the germination process.

The oil palm seeds have a low germination rate due to the dormancy following physiological maturity, caused by the

${ }^{3}$ Embrapa Amazônia Ocidental, Caixa Postal 319, 69010-970 - Manaus, AM, Brasil. ${ }^{4}$ Embrapa Solos, 22460-000, Rio de Janeiro, RJ, Brasil.

*Corresponding author <mgreen_37@yahoo.com.br> 
endocarp's hard and dense consistency, which gives mechanical strength to resist the absorption of oxygen, thus preventing the elongation of the embryo (Hussey, 1958). According to the author, under natural conditions, the germination of oil palm seeds can take years, and it is often uneven and has a very low rate. For the germination of commercial seeds, it is necessary to break dormancy, usually through heat-treatment.

Hussey (1958) was the first author to shed light on the use of temperature to break dormancy of oil palm seeds by finding out that the optimum temperature for overcoming dormancy in teneratype oil palm seeds was between 38 and $40{ }^{\circ} \mathrm{C}$. Heat-treatment was also studied by Rees (1962), who concluded that, to break seed dormancy, the water content of the seeds must be above $17 \%$ when they are subjected, for 70 to 80 days, to a temperature of $39.5^{\circ} \mathrm{C}$. Hussey's study (1958) showed that the germination of oil palm seeds depends on a minimum concentration of oxygen in the embryonic tissues and that seeds with a high water content have water blocking the intercellular spaces, which hinders the permeability of the endocarp to oxygen, leading to dormancy as a result of the mechanical strength to resist the absorption of oxygen.

Since then, several germination protocols for oil palm seeds have been developed based on heat-treatment to break dormancy (Hussey, 1958; Rees, 1962; Pinto, 1971; Mok, 1982; Addae-Kagyah et al., 1988; Corrado and Wuidart, 1990, among others). More recent studies on the effects of heat-treatment duration on the germination of oil palm seeds were led by Beugré et al. (2009) and Fondom et al. (2010).

The effect of genotype, storage period and heat-treatment duration on the germination was studied by Beugré et al. (2009) with seeds of two oil palm breeding lines (LM 19954 and LM 19617). Freshly-harvested seeds and seeds stored for three and six months at $21 \pm 1{ }^{\circ} \mathrm{C}$ and relative humidity of $60 \%$ before heattreatment were used. The breaking of dormancy was obtained with heat-treatment for 40, 60 and 80 days at a temperature of $39 \pm 1{ }^{\circ} \mathrm{C}$. After heat-treatment, the seeds were hydrated for five days, packed in polyethylene bags and placed to germinate at $26 \pm 1{ }^{\circ} \mathrm{C}$ for eight weeks. The authors concluded that the seed germination capacity was highly influenced by genotype and that the heat-treatment duration of 60 days promoted the highest germination rate as compared to other time periods.

Using seeds of 10 progenies stored for three months and at a humidity level adjusted to $18 \%$, Fondom et al. (2010) studied the effects of heat-treatment on oil palm seed germination and seedling growth. The seeds were packed in polyethylene bags and placed in the germinator for 60, 80, 100 and 120 days, at a temperature of $39 \pm 1{ }^{\circ} \mathrm{C}$. According to the authors, the heattreatment duration of 60 days was also effective for breaking dormancy of seeds of the 10 progenies studied.

For the germination of oil palm seeds, Embrapa
Western Amazon uses the method described by Corrado and Wuidart (1990) that consists in hydrating the seeds for seven days before heat-treatment, with water renewed daily. Next, the seeds are dried at room temperature until the water content is around $18 \pm 0.5 \%$ and packed in sealed polyethylene bags. Subsequently, the seeds are placed in the germinator at a temperature of $39 \pm 1^{\circ} \mathrm{C}$ for 80 days and then rehydrated for seven days until reaching a moisture content between 23 and $25 \%$. The seeds are then packed in sealed polyethylene bags and placed in the germination room at a temperature of $26 \pm 1{ }^{\circ} \mathrm{C}$. After seven days, the first screening (count) is done to identify the germinated seeds (protrusion of the hypocotyl-radicle axis). Three other screenings follow on a weekly basis. This pregermination process takes 120 to 150 days, approximately. By refining this procedure, seed germination may increase and the time required for germination may be reduced, resulting in a lower cost of production.

Hence, the aim of this study was to evaluate the effect of heat-treatment durations on the germination of seeds of six oil palm cultivars.

\section{Materials and Methods}

The study was conducted in the Laboratory of Palm Oil and Agroenergy of Embrapa Western Amazon, located on km 29 of the AM 010 highway, latitude $2^{\circ} 53^{\prime} 23.44$ ” S, longitude 5958'57.30” W, in Manaus, AM, Brazil.

Seeds of six oil palm cultivars produced by Embrapa Western Amazon were used, namely: BRS C2001, BRS C2328, BRS C2501, BRS C2528, BRS C3701 and BRS C7201. The seeds were produced following the procedures described by Cunha et al. (2007). After harvesting, the fruits were removed manually from the bunch and the mesocarp was extracted in a centrifugal electric pump. Subsequently, the seeds were dried in the shade and the ones that were misshapen or damaged by processing were discarded. Then, they were treated with systemic and contact fungicide with Carboxin ${ }^{\circledR}+$ Thiram ${ }^{\circledR} 200 \mathrm{SC}$ at $0.2 \%$, for five minutes.

The seeds of each cultivar were divided into lots of 500 seeds each and their water content of the lots was adjusted to $18.0 \pm$ $0.5 \%$. As the initial average water content of the seed lots was $21 \%$, the seeds were dried in the shade until reaching a moisture content of $18 \%$. The moisture content of the seeds was determined using the oven method at $105^{\circ} \mathrm{C} \pm 3{ }^{\circ} \mathrm{C}$, for 24 hours, following Brasil (2009), with four replicates of 10 seeds for each lot.

Next, the lots were placed in $65 \times 50 \mathrm{~cm}, 0.2$-mm-thick sealed polyethylene bags, with a volume of air at least equal to the volume of seed, and placed in the germinator at a temperature 
of $39 \pm 1{ }^{\circ} \mathrm{C}$ and relative air humidity of approximately $80 \%$ for periods of 40, 50, 60 and 80 days. The seeds were inspected every two weeks and, in case of fungal contamination, the infected lots were treated with systemic and contact fungicide with Carboxin ${ }^{\circledR}+$ Thiram ${ }^{\circledR} 200 \mathrm{SC}$ at $0.2 \%$, for five minutes.

After each heat-treatment period, the seeds were hydrated for seven days by immersing the bags, which were previously perforated, in tanks with water being replaced twice daily. To remove the excess water, after hydration, the seeds were dried in the shade, over a wire screen, at room temperature.

The seeds were then placed in properly sealed $(65 \mathrm{~cm} \mathrm{x}$ $50 \mathrm{~cm}, 0.2-\mathrm{mm}$-thick) polyethylene bags, with a volume of air at least equal to the volume occupied by the seeds, and kept in the germination room at a temperature between 27 and $30^{\circ} \mathrm{C}$.

The germinated seeds were counted four times, the first one 15 days after conditioning the seeds in the germination room and the others weekly. A seed was considered germinated when there was protrusion of the hypocotylradicle axis, characterized by the resumption of the growth of the embryo or by the visible emission of the radicle (Hussey, 1958; Bewley and Black, 1994). During the counts, when the presence of fungi on the seeds was detected, the number of contaminated seeds and the disposal thereof were registered and the remaining seeds were treated with a sodium hypochlorite solution at $1 \%$. To calculate the germination percentage, the seeds discarded due to contamination and the ungerminated ones were considered ungerminated.

The experimental design was a randomized block with four replications of 500 seeds each, in a 6 x 4 factorial design (six oil palm cultivars and four heat-treatment durations for breaking dormancy), totaling 24 treatments and 96 plots.

Firstly, an analysis of variance was carried out to determine the effect of the factors and the interaction between them. Once a significant interaction of the factors was found, a decomposition analysis was performed. The mean germination rates of the cultivars within each heat-treatment period were compared using the Tukey test at a probability level of $5 \%$, and regression analysis was used to assess the effect of the heat-treatment duration on the germination of seeds of each cultivar. Statistical analyses were performed using SAS software (SAS, 2002). The regression equations were chosen based on best fit, using the Table Curve program (Jandel Scientific, 1989).

\section{Results and Discussion}

There was a significant effect $(\mathrm{p} \leq 0.05)$ of the cultivars and the heat-treatment duration as well as the interaction cultivar $\mathrm{x}$ heat-treatment duration on the germination of oil palm seeds
(Table 1). In the decomposition of the degrees of freedom of the interaction, a significant effect of the duration of heattreatment on cultivars BRS C2001, BRS C2328, BRS C2501, BRS C2528 and BRS C3701, and of the cultivars within the heat-treatment periods was found. The coefficient of variation $(10.9 \%)$ showed satisfactory experimental precision, which allowed for a proper determination of the mean values.

Statistical differences among cultivars were observed at all durations of heat-treatment evaluated (Table 2). The mean germination rates for each time period were $61 \%$ in 40 days, $73 \%$ in 50 days, $77 \%$ in 60 days and $60 \%$ in 80 days. With the heat-treatment for 40 days, germination varied from $40 \%$ (BRS C3701) to $81 \%$ (BRS C7201), for 50 days it was between $64 \%$ (BRS C3701) and 88\% (BRS C7201), for 60 days it ranged from 58\% (BRS C2328) to 89\% (BRS C2501), and for 80 days from $3 \%$ (BRS C2328) to $87 \%$ (BRS $\mathrm{C} 2501)$. The mean seed germination percentages of the cultivars were closer to each other in heat-treatment for 50 days $(\mathrm{CV}=$ $11.7 \%$ ) and more variable in the 80-day duration ( $\mathrm{CV}=$ $56.6 \%)$. In the 40-day-long heat-treatment, seeds of cultivar BRS C7201 had the highest germination percentage with no statistical difference from those of cultivar BRS C2328. In the 50-day-long heat-treatment, the highest germination rate was also obtained in the seeds of cultivar BRS C7201, but with no statistical difference from cultivar BRS C2501. With 60 days of heat-treatment, the seeds of cultivar BRS C2501 had the highest mean germination rate and did not differ significantly from BRS C7201, BRS C2528 and BRS C 3701. In the longest heat-treatment duration, 80 days, the highest mean germination rate was found in the seeds of cultivar BRS C2501, which did not differ statistically from the seeds of cultivars BRS C2528 and BRS C7201. The variation in the classification of the cultivars in different durations of heattreatment is due to the interaction between genotype and time and indicates that a suitable duration should be set for each genotype or group of genotypes.

By analyzing the response of two breeding lines of dura-type oil palm seeds, Beugré et al. (2009) found that, for both lines, the highest percentage of germination was obtained at 60 days. This result is consistent with the average germination percentage of the seeds of the cultivars analyzed in this study, given that, in the heattreatment duration of 60 days, the mean seed germination of the cultivars, $77 \%$ (Table 2), was higher than in the other durations. The results found by Fondom et al. (2010) also corroborate the findings of this study. By analyzing the germination of 10 progenies of oil palm, the authors observed that seeds with a moisture content of $18 \%$ germinated better when subjected to a temperature of $39 \pm 1{ }^{\circ} \mathrm{C}$ for 60 days, as compared to the durations of 80,100 and 120 days. 
Table 1. Summary of analysis of variance of seed germination in six oil palm cultivars subjected to four heat-treatment durations at $39 \pm 1^{\circ} \mathrm{C}$.

\begin{tabular}{lccc}
\hline \multicolumn{1}{c}{ Sources of Variation } & Degrees of Freedom & Mean Squares & F-values \\
\hline Blocks & 3 & 443.47 & 2.01 \\
Cultivars & 5 & 2432.44 & 32.81 \\
HT Duration & 3 & 1785.25 & 22.26 \\
Cult. x HT Duration & 15 & 1211.40 & $27.88^{* *}$ \\
\hline Cult./HT Duration & 20 & 1516.66 & $14.11^{* *}$ \\
$\quad$ Cult./40-day duration & 5 & 767.82 & $5.39^{* *}$ \\
Cult./50-day duration & 5 & 293.55 & $8.67^{* *}$ \\
$\quad$ Cult./60-day duration & 5 & 471.58 & $83.33^{* *}$ \\
$\quad$ Cult./80-day duration & 5 & 4533.68 & $24.02^{* *}$ \\
HT Duration/BRS C2001 & 18 & 1307.04 & $20.65^{* *}$ \\
HT Duration/BRS C2328 & 3 & 1123.41 & $73.23^{* *}$ \\
HT Duration/BRS C2501 & 3 & 3984.27 & $16.73^{* *}$ \\
HT Duration/BRS C2528 & 3 & 910.36 & $6.68^{* *}$ \\
HT Duration/BRS C3701 & 3 & 363.45 & $25.52^{* *}$ \\
HT Duration/BRS C7201 & 3 & 1388.55 & $1.33^{\text {ns }}$ \\
\hline Residual & 3 & 72.20 & \\
\hline Mean & 69 & 54.41 & \\
\hline CV (\%) & 67.6 & & \\
\hline
\end{tabular}

ns, not significant $(\mathrm{p} \geq 0.05)$; ${ }^{* *}$ significant at a probability level of $1 \%$ by the F-test; Cult., cultivar; HT, heat-treatment.

Table 2. Mean germination rate (\%) of seeds of six oil palm cultivars subjected to four heat-treatment durations at $39 \pm 1{ }^{\circ} \mathrm{C}$.

\begin{tabular}{ccccc}
\hline Cultivar & 40 days & 50 days & 60 days & 80 days \\
\hline BRS C2001 & $60 \mathrm{bc}$ & $68 \mathrm{~b}$ & $71 \mathrm{bc}$ & $34 \mathrm{c}$ \\
BRS C2328 & $69 \mathrm{ab}$ & $68 \mathrm{~b}$ & $58 \mathrm{c}$ & $3 \mathrm{~d}$ \\
BRS C2501 & $56 \mathrm{bc}$ & $76 \mathrm{ab}$ & $89 \mathrm{a}$ & $87 \mathrm{a}$ \\
BRS C2528 & $60 \mathrm{bc}$ & $74 \mathrm{~b}$ & $80 \mathrm{ab}$ & $81 \mathrm{ab}$ \\
BRS C3701 & $40 \mathrm{c}$ & $64 \mathrm{~b}$ & $82 \mathrm{ab}$ & $75 \mathrm{~b}$ \\
BRS C7201 & $81 \mathrm{a}$ & $88 \mathrm{a}$ & $81 \mathrm{ab}$ & $78 \mathrm{ab}$ \\
\hline Mean & 61 & 73 & 77 & 60 \\
\hline CV (\%) & 22.7 & 11.7 & 14.1 & 56.6 \\
\hline
\end{tabular}

Means within each column followed by the same letter are not significantly different by the Tukey test at $5 \%$ of probability. ${ }^{1} \mathrm{CV}(\%)=(100 * \mathrm{SD}) /$ mean of cultivars.

In this study, there was a significant interaction between treatment time and its effect on cultivars, indicating differential response of the cultivars within each duration of heat-treatment (Table 2). The significant interactions between genotypes and heat-treatment durations can be explained by the genetic variability of the cultivars studied.

Regression analyses of the germination of oil palm seeds in relation to the duration of heat-treatment for each cultivar showed different time periods to obtain maximum germination, and the quadratic regression model was found to be the best fit to the data, except for cultivar BRS C2528, in which the linear model was the most suitable, and cultivar BRS C7201, in which none of the models tested fit the data (Figure 1).

The maximum germination values estimated by the regression analyses ranged from $70 \%$ (45 days of heattreatment) for cultivar BRS C2328 to $92 \%$ (69 days of heattreatment) for cultivar BRS C2501 (Figure 1, Table 3). The differences suggested that, for maximum germination, the seeds of each cultivar must undergo heat-treatment for a specific period of time. These results demonstrated that with a simple change in the heat-treatment consisting in the adoption of particular durations for each cultivar rather than the use of a standardized duration for all cultivars, which is the current rule (Cunha et al., 2007), it is possible to increase the seed germination rate and thus lower the cost of production, by reducing energy consumption with the use of the germinator and workforce for the periodic evaluation of the seeds during the germination process. For example, in the case of cultivar BRS C2328, the heating time for maximum germination was estimated at 45 days, 35 less than the duration recommended by the method described by Corrado and Wuidart (1990) currently being used (Cunha et al., 2007).

Mok (1982) evaluated the effect of heat-treatment 
durations of 20, 40 and 60 days on the germination of oil palm seeds, freshly harvested (FH) and at 1, 2, 4, 8 and 12 months of storage (MS) and obtained a germination rate ranging from $44 \%(\mathrm{FH})$ to $63 \%$ (2 MS) in seeds with 20 days of heattreatment, from $45 \%$ (12 MS) to $87 \%$ (1 MS) in seeds with 40
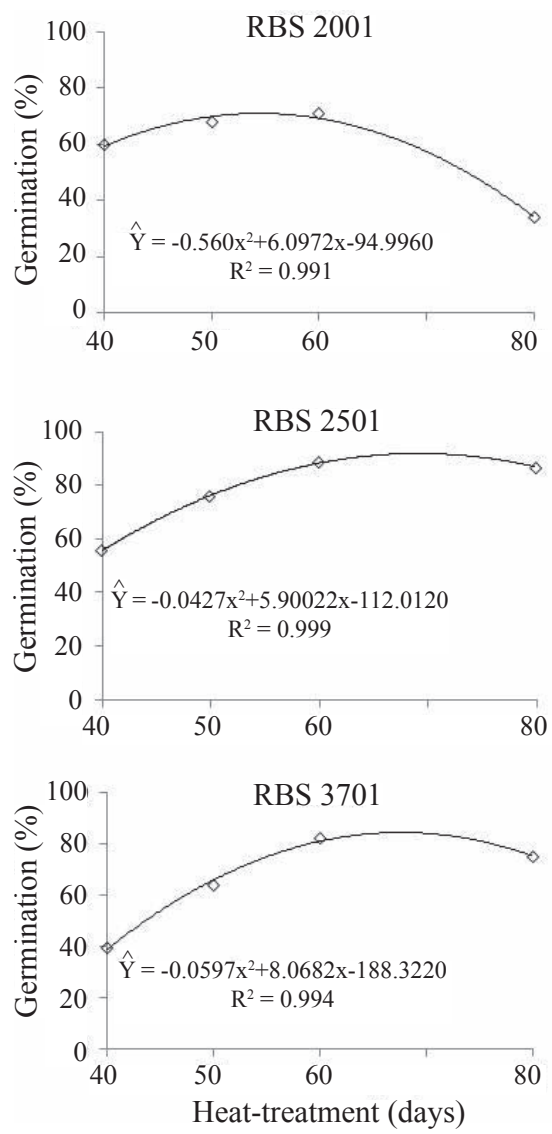

days and from 39\% (12 MS) to 93\% (1 MS) in seeds with 60 days. Similar results were found in this study when comparing the heat-treatment duration of 40 days, ranging from $40 \%$ to $81 \%$ of germination, and the heat-treatment of 60 days, with germination between $58 \%$ and $89 \%$.
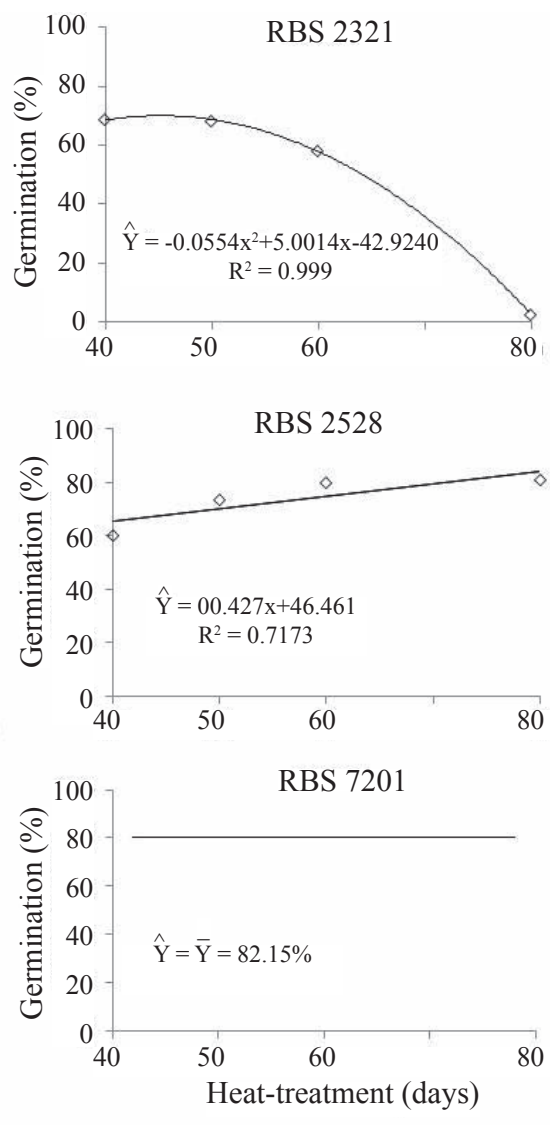

Figure 1. Seed germination (\%) of six oil palm cultivars in relation to the heat-treatment duration at $39 \pm 1{ }^{\circ} \mathrm{C}$.

\section{Conclusions}

Table 3. Maximum germination rate $(\hat{Y} \max )$ and corresponding heat-treatment duration $(\mathrm{t})(\hat{\mathrm{Y}}$ max)) for seeds of six oil palm cultivars.

\begin{tabular}{ccc}
\hline \multirow{2}{*}{ Cultivars } & $\mathrm{t}(\hat{\mathrm{Y}} \max )$ & $\hat{\mathrm{Y}} \max$ \\
\cline { 2 - 3 } & days & $\%$ \\
\hline BRS C2001 & 54 & 71 \\
BRS C2328 & 45 & 70 \\
BRS C2501 & 69 & 92 \\
BRS C2528 & 80 & 84 \\
BRS C3701 & 67 & 84 \\
BRS C7201 & $40-80$ & 82 \\
\hline
\end{tabular}

The maximum germination of commercial oil palm seeds varied according to the duration of heat-treatment at $40{ }^{\circ} \mathrm{C}$.

With the exception of cultivar BRS C2528, the amount of time the seeds remain in the germinator in order to break dormancy can be less than 80 days, which enables a reduction of $11,13,26,35$ and 40 days in the duration of heat-treatment for oil palm cultivars BRS C2501, BRS C3701, BRS C2001, BRS C2328 and BRS C7201, respectively.

\section{Acknowledgements}

The authors thank the Universidade Federal do Amazonas (UFAM) for the Graduate Program in Tropical Agronomy; the Foundation for Research Support of the State of Amazonas 
(FAPEAM) for granting a $\mathrm{PhD}$ scholarship to the first author mentioned above; Embrapa Western Amazon, for carrying out the works; the team of the Laboratory of Palm Oil and Agroenergy and technicians Raimundo Oliveira do Nascimento and Antonio Raimundo Soares da Silva, from Embrapa, for supporting research activities.

\section{References}

ADDAE-KAGYAH, K.A.; OSAFO, D.M.; OLYMPIO, N.S.; ATUBRA, O.K. Effect of seed storage, heat pretreatment and its duration on germination and growth of nursery stock of the idolatrica palm Elaeis guineensis var. idolatrica (Chevalier). Tropical Agriculture, v.65, n.1, p.77-83, 1988. http:// agris.fao.org/agris-search/search/display.do?f=2005\% $2 \mathrm{fgh} \% 2 \mathrm{fxmldc} 212$. xml\%3bgh2005100212

BEUGRÉ, M.M.; KOUAKOU, L.K.; BOGNONKPÉ, P.J.; KONAN, E.K.; KOUAKOU, H.T.; KOUADIO, J.Y. Effect of storage and heat treatments on the germination of oil palm (Elaeis guineensis Jacq.) seed. African Journal of Agricultural Research, v.4, n.10, p.931-937, 2009. http://www. academicjournals.org/ajar/pdf/pdf\%202009/oct/martine\%20et\%20al.pdf

BEWLEY, J.D.; BLACK, M. Seeds: physiology of development and germination. New York: Plenum Press, 445p. 1994.

BRASIL. Ministério da Agricultura, Pecuária e Abastecimento. Regras para análise de sementes. Ministério da Agricultura, Pecuária e Abastecimento. Secretaria de Defesa Agropecuária. Brasília: MAPA/ACS, 2009. 395p. http:// www.bs.cca.ufsc.br/publicacoes/regras\%20analise\%20sementes.pdf

CORRADO, F.; WUIDART, W. Germination des graines de palmier à huile ( $E$. guineensis) em sacs de polyétylène. Méthode par "charleursèche". Oléagineux, v.45,n.11,p.511-514, 1990. http://www.cabdirect.org/abstracts/19920312796. $\mathrm{html}$; jsessionid=42a420545b790911114d263e398118f5?freeview $=$ true
CUNHA, R.N.V.; LOPES, R.; DANTAS, J.C.R.; ROCHA, R.N.C. Procedimentos para produção de sementes comerciais de dendezeiro na Embrapa Amazônia Ocidental. Manaus: Embrapa Amazônia Ocidental, 2007. 34p. (Embrapa Amazônia Ocidental. Documentos, 54).

FONDOM, N.Y.; ETTA, C.E.; MIH, A.M. Breaking Seed Dormancy: Revisiting Heat-treatment Duration on Germination and Subsequent Seedling Growth of Oil Palm (Elaeis guineensis Jacq.) Progenies. Journal of Agricultural Science, v.2, n.2, p.101-110, 2010. http://www.cabdirect.org/ abstracts/20113238443.html

HUSSEY, G. An analysis of the factors controlling the germination of seed of the oil palm, Elaeis guineensis (Jacq.). Annals of Botany, v.22, n.86, p.259284, 1958. http://aob.oxfordjournals.org

JANDEL SCIENTIFIC. Table Curve for windows. Version 1.10. Jandel Scientific, 1989.

MOK, C.K. Heat requirement for breaking dormancy of the oil palm seeds after storage under different conditions. In: PUSHPARAJAH, E.; CHEW, P.S. (Eds.). The Oil Palm in Agricultural Development in the Eighties. Kualar Lumpur, Malaysia: The Incorporated Society of Planters, 1982. p.197-206.

PINTO, M.F. Germinação acelerada de sementes de palmeira. Agronomia Angolana, n.31, p.41-56, 1971.

REES, A.R. High-temperature pre-treatment and germination of seed of oil palm, Elaeis guineensis (Jacq.). Annals of Botany, v.26, n.4, p.569-581, 1962. http://aob.oxfordjournals.org/search?fulltext=Rees $\% 2 C+A . R .+v .26 \% 2 C+n$. $104 \% 2 \mathrm{C}+$ p. $569-581 \% 2 \mathrm{C}+1962 \&$ submit $=$ yes $\& \mathrm{x}=0 \& \mathrm{y}=0$

SAS INSTITUTE INC. SAS system for Microsoft windows. Version 9. Cary, 2002.

USDA. United States Departament of Agriculture. Economics, Statistics, and Market Information System. Available on: http://www.fas.usda.gov/ psdonline/circulars/oilseeds.pdf. Accessed on: 21 $1^{\text {st }}$ Aug. 2012. 